\title{
PROSPECT FOR GOLD AND OTHER PRECIOUS METALS IN META- IGNEOUS ROCKS OF SRI LANKA: IMPLICATIONS FROM GEOCHEMISTRY
}

\author{
SANJEEWA P.K. MALAVIARACHCHI ${ }^{1,2}$, P.L. DHARMAPRIYA ${ }^{1,2}$, H.M.D.A.H. \\ BANDARA $^{2,3}$, M.H. KODIKARA ARACHCHI ${ }^{4}$, N.D. SUBASINGHE ${ }^{3}$ \\ ${ }^{1}$ Department of Geology, Faculty of Science, University of Peradeniya, Peradeniya, Sri \\ Lanka \\ ${ }^{2}$ Postgraduate Institute of Science, University of Peradeniya, Peradeniya, Sri Lanka \\ ${ }^{3}$ National Institute of Fundamental Studies, Hantana Road, Kandy, Sri Lanka \\ ${ }^{4}$ National Building Research Organization, Jawatte Road, Colombo 7, Sri Lanka \\ *Corresponding author e-mail: malavi@pdn.ac.lk
}

(Received $24^{\text {th }}$ July 2018; accepted $11^{\text {th }}$ January 2019)

\begin{abstract}
This study presents some major, trace and precious metal geochemistry of some representative meta-igneous rocks from the Highland and Vijayan Complexes and Kataragama Kilippe (HC, VC, KK, respectively) of Sri Lanka. Our data show different geochemical trends in chemical-discrimination diagrams, indicating each lithological unit has distinct genetical environments. Most of the mafic samples of the $\mathrm{HC}$ and the $\mathrm{KK}$ fall geochemically in the tholiietic field. In contrast, the garnetiferrous charnockitic samples of the $\mathrm{HC}$ and majority of the VC samples plot in the calc-alkaline field. Rocks of the VC and $\mathrm{KK}$ and mafic rocks of $\mathrm{HC}$, deviate from typical magmatic differentiation patterns probably due to a later interaction with secondary melts or fluids. There is a clear distinction of $\mathrm{Pt} / \mathrm{Pd}$ and $\mathrm{Au} / \mathrm{Pt}$ vs. $\mathrm{MgO}$, in which all the samples except for the garnetiferrous charnockites of the $\mathrm{HC}$ show a negative correlation implying a sequestration of chalcophile melts from protolith magmas. Therefore, our data indicate that possibility of occurrence of gold ( $\mathrm{Au})$ and other precious metals (e.g. Pt and Pd) within the meta-igneous rock units of the HC, $\mathrm{VC}$ and $\mathrm{KK}$ is reasonable except for the garnetiferrous charnockitic rocks of the HC. The garnetiferrous charnockites of the $\mathrm{HC}$ do not account for any geochemical evidence sensitive to precious metal enrichments in protoliths. Our estimates show that the highest (in average) Au, Pt and Pd contents are found in the rocks of VC ( $8 \mathrm{mg} / \mathrm{ton}), \mathrm{KK}$ (7 mg/ton) and $\mathrm{HC}(7 \mathrm{mg} / \mathrm{ton})$, respectively. Although these precious metal abundances in the above prospective rock units are not as high as those present in global ore-grade rocks, yet 'hard rock mining' technique could be feasible to utilize as a small-scale industry to extract these metals, especially using rock-aggregates/rock powders dumped as wastes from rock quarries in Sri Lanka.
\end{abstract}

Keywords: Gold, Platinum group elements, Hard rock mining, Gondwana, Sri Lanka 


\section{INTRODUCTION}

Precious metals include gold $(\mathrm{Au})$, copper $(\mathrm{Cu})$ and Platinum Group Elements (PGE) namely, platinum (Pt) , palladium (Pd) , iridium (Ir) , osmium (Os), rhodium $(\mathrm{Rh})$ and ruthenium $(\mathrm{Ru})$, originate mainly from magmatic fluids exsolved from sulphide-saturated magmas which occur predominantly in arc-related settings such as subduction zones (Burnham, 1967; Campbell and Barnes, 1984; Setiabudi et al. 2007). Due to their non-reactivity with atmospheric oxygen most of these metals are also called 'noble metals'.

These metals fall essentially to the 'siderophile' categolry of elements (Goldschmidt, 1937). However, it is also observed that the PGE, Au and $\mathrm{Cu}$ behave as 'chalcophile' in magmatic systems in the absence of metallic phases (e.g. metal-Fe absent/metal-Fe poor chemical systems) and their chalcophile nature becomes more enhanced when low-redox or reducing conditions are present (Campbell and Barnes, 1984; Setiabudi et al. 2007 and references therein). In such cases, these metals tend to partition into sulphide-bearing phases/magmatic sulphide-melts due to their very high partition coefficients (usually $>10^{4}$ ) with respect to sulphide/sulphur-bearing chalcophile melts (Campbell and Barnes, 1984; Setiabudi et al. 2007; Mungall and Brenan, 2014).

Most of the precious metal deposits of the world are found associated with very old volcanic rocks (Proterozoic to Precambrian), and occur in melt-crystallized veins (Boyle, 1979). Studies have found that water-rich arc magmas may play an important role in the formation of these metals in rocks (McInnes et al. 1999; Sillitoe, 2010; Hao et al. 2017). However, only a limited number of arc igneous suites host economically exploitable large precious metal deposits due to certain prerequisites. These include but not limited to, (1) a magma need to be enriched in metals, (2) efficient transfer of the metals by exsolved magmatic fluids is not hampered and (3) precipitation of the metals in a localized area is naturally facilitated (Richards, 2003; Audétat and Simon, 2012; Wilkinson, 2013). All these pre-requisites may not be satisfied concurrently, hence such deposits do not occur frequently in the Earth. In general, PGE and $\mathrm{Au}$ are dominantly affected by sulfide saturation during magma differentiation due to their strong chalcophile nature and weak affinity to silicate minerals (Mungall and Brenan, 2014). Such sulphide melts once formed, are immiscible in silicate magma and hence leave the original magma forming a calcophile metal enriched deposit in a separate channel (e.g. Campbell and Barnes, 1984; Setiabudi et al. 2007). Alternatively, for a magma to be Au and PGE rich to produce mineral deposits, long term differentiation of sulfide undersaturated magmas or initial metal enriched mantle which is fertile enough to generate melt, are needed (McInnes et al. 1999; Mungall, 2002; Jenner et al., 2010; Wilkinson, 2013; Park et al., 2015).

Compared with other chalcophile elements, the PGE (at least Pt and Pd) and Au have much higher partition coefficients in calcophile magmatic systems (Francis, 1990; Peach et al.,1994). Further, compatible to moderately incompatible nature of the PGE makes these elements powerful tools in studying magmatic processes (Francis, 1990; Peach et al., 1994; Bezmen et al., 1994; Fonseca et al., 2009). On the other hand, studies on igneous rocks (e.g. Campbell and Barnes, 1984; Setiabudi et al. 2007; Park et al., 2013;2015; 2016; Cocker et al., 2015; Hao et al., 2017) have shown that Au and PGE behave in an immobile manner, which facilitates formation of Au-PGE enrichments in rocks crystallizing from magma. Therefore, constraints on chalcophile element geochemistry in igneous/meta-igneous rocks can provide important implications on magma evolution.

Variations in trace-element abundances in both igneous and meta-igneous rocks can be used to gain insights into the composition of the source regions and the physical processes involved in melting, magmatic differentiation and subsolidus evolution during metamorphism (see Rollinson,1993 for a comprehensive review). Trace elements, defined as those 
present at concentrations $<0.1 \mathrm{wt} . \%$ in rocks, are usually not sufficient to form their own mineral phases in rocks. However, they substitute to varying degrees in existing mineral structures, depending on their ionic size and charge (Rollingson, 1993). During partial melting, the trace element partitioning between the residual mineral phases and coexisting liquid (magma) is occurred. In this process, incompatible elements partition dominantly into the liquid phase while compatible trace elements remain in the residue/solid. In addition to trace element abundances, trace element ratios are particularly useful to understand magmatic processes which might not be detected by elemental abundances and can provide more information on processes that may have occurred during magmatic differentiation and evolution of a magmatic protolith (e.g. Rollingson, 1993; Thirlwall et al., 1994).

Therefore, in this study, we use both trace elements and some specific trace element ratios together with major elements as geochemical constraints to elucidate the possibility for occurrence of gold and other precious metals in the studied meta-igneous rocks of Sri Lanka. Further, our attempt is a test on the protolith geochemistry of meta-igneous rocks of variable bulk composition (from ultramafic-mafic to granitic) by comparing their $\mathrm{Au}$ and PGE geochemistry. Hence, we present their major elements, rare earth elements, $\mathrm{Au}$ and PGE contents in order to obtain chemical constraints to discuss their evolution and evaluate the occurrence of precious metals in whole rock scale in some representative high-grade metaigneous rocks of Sri Lanka.

\section{OUTLINE GEOLOGY OF SRI LANKA}

The Sri Lankan Precambrian basement has been subdivided into four major terrains (e.g. Cooray, 1994), namely: Highland Complex (HC), Wanni Complex (WC), Vijayan Complex (VC) and Kadugannawa Complex (KC) (Fig. 1), based on $\mathrm{Nd}$ isotope model age mapping and zircon geochronology (Cooray, 1994; Milisenda et al., 1988; 1994; Kröner et al., 1987; 1991). The WC is located west of the $\mathrm{HC}$ although there is no clear structural break between the rocks of the two complexes or the contact has been obliterated by later deformation events (Voll and Kleinschrodt, 1991). The VC is exposed in eastern Sri Lanka and consists predominantly of meta-igneous rocks, which are upper amphibolite-facies calc-alkaline granitoid gneisses including augen-gneisses, with minor amphibolite layers possibly derived from mafic dykes. This granitoid suite was interpreted as a product of subduction-related magmatism (Pohl and Emmermann, 1991). The boundary between the $\mathrm{VC}$ and the $\mathrm{HC}$ is defined as a thrust/shear contact (Hatherton et al., 1975; Vitanage, 1985; Voll and Kleinschrodt, 1991; Kriegsman, 1995). Three tectonic klippens with petrological and structural features similar to the $\mathrm{HC}$ are exposed in the southeastern part of Sri Lanka as inliers, namely Kataragama Klippe (KK), Buttala Klippe and Kuda Oya Klippe. The HC domain is interpreted to be a part of a supracrustal basin developed in a suture zone with Lützow-Holm Complex in East Antarctica at the last phase of Gondwana assembly (Shiraishi et al., 1994). The $\mathrm{KC}$ is in contact with the WC and the HC. The $\mathrm{WC}, \mathrm{KC}$ and $\mathrm{VC}$ domains are interpreted to be originated in Grenville-age arc-related settings (Kröner et al., 2003; Willbold et al., 2004; Kröner et al., 2013).

\section{PRECIOUS METAL OCCURRENCE IN SRI LANKA: PREVIOUS REPORTS}

Occurrence of gold has been reported in historical chronicles such as Mahawamsa and Thuupawamsa, and also the traditional usage of place names such as Ranwala, Harankahawa etc. confirms its discovery and probable mining in larger quantities by ancient people of Sri Lanka. Early studies in $19^{\text {th }}$ century have confirmed occurrence of alluvial gold in small quantities, particularly in central, western and southern parts of Sri Lanka (see review of Dissanayake and Nawaratne, 1981). Fine particles of gold in gem bearing alluvial sediments and gravel beds have been studied by Dissanyake and Nawaratne, (1981) from southern and south-western Sri Lanka. The 
geochemistry of gold and platinum has been investigated in peat and algal mats of Sri Lanka by Dissanayake and Kritsotakis (1984). A study from Walawe river basin confirmed the occurrence of placer gold in quantities up to 9 g/ton (Nawaratne and Wijeratne, 1995; Nawaratne, 1996). These high gold contents (threshold values for gold in economic mining is $>1 \mathrm{~g} / \mathrm{ton}$ (Emawati et al. 2017; Kasrai et al. 1988) reflect long-term residual/alluvial enrichment of gold in river basins to which gold has been transported from basement rocks (such as those studied here) of Sri Lanka. A recent study by Malaviarachchi and Dharmapriya, 2014 showed occurrence of gold and PGE in sulphide-saturated Mg-rich lithologies of the HC of Sri Lanka.

\section{ANALYTICAL TECHNIQUES}

Rock thin sections were prepared for petrography under polarizing microscope at the Department of Geology, University of Peradeniya and National Institute of Fundamental Studies, Kandy. Representative samples devoid of surface alteration or weathering were used for major, trace, PGE and $\mathrm{Au}$ analyses. The size of the samples were initially reduced in a jaw crusher, and then finepowdered in an agate mortar. Major oxides were analyzed by X-ray fluorescence (XRF) and rare earth elements, PGE and Au by inductively coupled mass spectrometry (ICP-MS) at Intertek Genalysis Laboratories, Australia. For XRF, lithium tetraborate fusion technique was applied. Ni-sulphide fire assay technique was employed for analysis of PGE and Au in the samples. The pulped samples were weighed $(25 \mathrm{~g})$ and mixed with a flux to be fired in a furnace. When fired, the flux sample mixed forms a nickel sulphide matte and an immiscible slag. The precious metals were collected in the nickel sulphide matte (button). The button is separated from the slag, weighed and pulverized. A portion of the pulverized button was weighed and dissolved in boiling $\mathrm{HCl}$. The addition of various reagents to the boiling $\mathrm{HCl}$ solution and careful observation of the dissolution process ensured that the PGE and $\mathrm{Au}$ were quantitatively recovered by filtration as insoluble residues. These residues were dissolved in aqua regia. The solution was diluted and analyzed on an ICP-MS with corrections for various interferences of polyatomic species. Internal standards were used to correct for drift and plasma fluctuations.

\section{SAMPLES, FIELD RELATIONS AND PETROGRAPHY}

The studied 18 rock samples (Fig. 1) include a wide range of composition, ranging from ultramafic-mafic to granitic, from the $\mathrm{VC}, \mathrm{KK}$ and HC of Sri Lanka. Detailed petrology of these rocks indicate that the samples are metamorphosed igneous rocks (meta-igneous rocks).

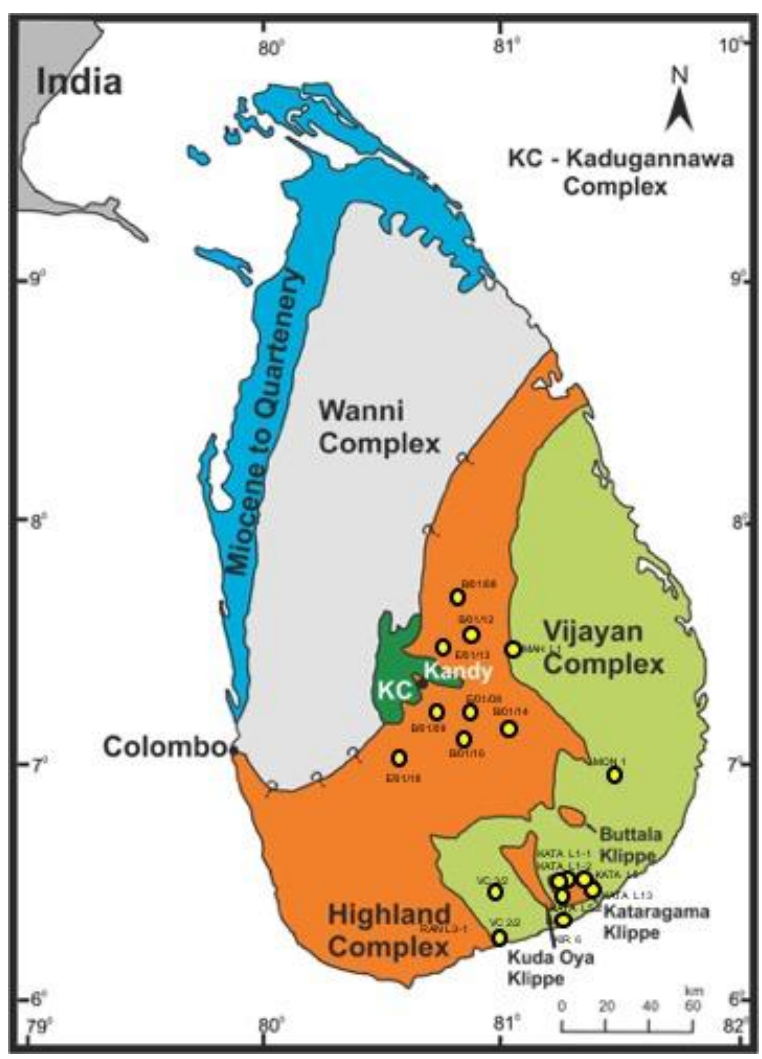

Fig. 1. Lithotectonic subdivision of Sri Lanka (after Cooray, 1994), showing the sample locations. 


\section{SAMPLES FROM THE VIJAYAN COMPLEX}

Hornblende-Biotite gneiss sample (KIR-6) was collected from an outcrop around Kirinda in Hambantota. The outcrop shows highly sheared structures and biotite defines the lineation observed in the outcrop. Migmatized portions of the rock could be identified in the outcrop. Fine grained hornblende, biotite and fine to medium grained quartz and feldspar are the major minerals observed in the rock.

A charnockitic gneiss (Mahi-L1) was collected from a quarry close to Mahiyanganaya. The massive looking charnockitic gneiss contains, few felsic veins, melt patches and boudinaged structures in the host rock containing pyrite along margins of the layers. Intense folding of felsic veins and presence of sheath folds in the rock indicates the tectonic deformation. The rock is composed of medium grained hypersthene and medium to coarser grained garnet, quartz, feldspar and garnets as major minerals.

The MON-1 is a partly migmatized charnockitic gneiss sample collected from a working quarry in Hulandawa, Moneragala. Coarse-grained hornblende and medium grained quartz and feldspar are observed in the migmatized portions within the host rock.

Sample VC2/2 and VC3/2 are ultramafic rocks (altered to serpentinites) from Ussangoda and Indikolapelessa, respectively, along the boundary of the Vijayan and Highland Complexes, studied previously for petrology and geochemistry in He et al. 2016. The rocks occur as large enclaves in quartzite and limonitised rock. The sample VC $2 / 2$ is fine grained and green coloured, probably containing some hydrous silicate minerals altered after original olivine in the peridotitic protolith. These samples contain serpentine (over 95 vol.\%) with minor magnetite and most of the serpentine are antigorite showing pseudomorphic texture of olivine with oriented cracks indicating that the serpentine replaced olivine (see details in $\mathrm{He} e t$ al. 2016).

\section{SAMPLES FROM THE KATARAGAMA KLIPPE}

The sample KATA/L1-1 is a charnockitic gneiss sample collected from an outcrop in Beralihela, Kataragama along the Weerawila-Kataragama road. Formation of hypesthene + plagioclase Corona around very coarse-grained garnet can be identified even in the hand specimen. Coarser grained garnets and fine to medium grained quartz, hornblende, feldspar and fine-grained biotite are observed as the major minerals composing the rock.

The charnockitic sample of KATA/L1-2 sample was collected in a quarry near Gam Udawa site in Kataragama. The rock contains felsic and mafic intrusions parallel to the weak foliation plane. The analyzed rock is composed of finegrained garnets, quartz, feldspar and biotite together with medium grained hypersthene.

The sample KATA/L3 is also from Kataragama, a granitic gneiss sample containing garnet, quartz, plagioclase, iron ore and perthite as the major minerals. Perthites are medium to coarser grained and garnet is fine to medium grained with myrmekitic quartz, plagioclase and iron ore, occurring as fine-grained minerals.

A highly sheared hornblende-biotite gneiss sample (KATA/L-5) was collected from a working quarry in Galhena near Kataragama. Few melt patches can be identified in the rock. Fine grained biotite, fine to medium grained quartz and feldspar and medium grained hornblende are observed as the major minerals of the rock.

The KATA/L13 charnockitic gneiss sample was collected from a working quarry near Andarawewa in Kataragama. Pegmatitic and few mafic intrusions are observed in the massive looking host charnockitic gneiss. Coarser grained coronal garnets are observed with the plagioclase and hypersthene in the corona. Fine grained hypersthene and medium to coarser grained quartz and feldspar are the major minerals observed in the matrix of the host rock. 


\section{SAMPLES FROM THE HIGHLAND COMPLEX}

\section{Mafic granulites}

The sample of two pyroxene-biotite gneiss (B/01/08) was collected from a road exposure close to Lenadora. The rock occurs as blocks (1$3 \mathrm{~m}$ diameter) within host marble. The mafic rock contains two pyroxenes and plagioclase as major mineral phases, where the modal abundance of clinopyroxene (45\%) is higher than that of orthopyroxene (7\%). Biotite present as a minor mineral and coarse phlogopite flakes are present at the contact between marble and mafic granulite.

Garnet-clinopyroxene-hornblende gneiss sample (B/01/09) was collected from a quarry at Ambuluwawa. This mafic rock occurs as blocks and discontinuous layers within host granitic gneiss. The samples contain anhedral, medium to coarse-grained $(0.5-1.5 \mathrm{~cm})$ clinopyroxene as well as medium to coarse-grained anhedral garnets $(0.2-1.5 \mathrm{~cm})$ and anhedral, mediumgrained hornblende $(0.2-0.5 \quad \mathrm{~cm})$. Orthopyroxene-plagioclase symplectites frequently rim garnets. Biotite is present as a minor mineral.

The Sample B/01/12 is a garnet-bearing mafic granulite, collected from a road exposure close to Hunnasgiriya where the rock is found as a discontinuous layer within a host charnockite. The handspecimen contain anhedral medium to coarse $(0.25-1 \mathrm{~cm})$ clinopyroxene and recrystallised feldspars as major mineral constituents. Medium to coarse anhedral garnets $(0.25-0.75 \mathrm{~cm})$ are present as a minor phase. Occasionally, garnets are rimmed by orthopyroxene -plagioclase symplectites.

In the Haputale escarpment, a mafic granulite (B/01/14) was collected. This mafic granulite occurs as a thick layer (several tens of meters), in contact with a charnockite. Rock contains medium to coarse grained anhedral garnets $(0.25$ $-1 \mathrm{~cm})$ and clinopyroxene $(0.25-0.75 \mathrm{~cm})$.

The mafic granulite sample $B / 01 / 16$ was collected from boulders in a small stream close to Koslanda. Since the river has a very restricted catchment area, the source rock of the boulder could be located as close-by. Also, there are various sizes of mafic boulders (from several centimeters to $>1.5 \mathrm{~m}$ ) were present at the vicinity of this location. The collected samples contain porphyroblastic garnet $(0.3-1 \mathrm{~cm})$ and anhedral medium to coarse clinopyroxene. Frequently the garnets have broken down forming plagioclase-orthopyroxene symplectites.

\section{Garnetiferrous charnockites}

A garnet-bearing charnockite (E/01/08) was collected from a road exposure along the Randenigala-Mahiyanganaya road close to Randenigala Dam where the charnockite occurs as a massive layer adjacent to a meta-granite. The charnockite contains anhedral porphyroblastic garnet (up to $1 \mathrm{~cm}$ in diameter), fine to medium grained orthopyroxene $(0.2-$ $0.75 \mathrm{~cm})$, recrystallised feldspars and medium to coarse-grained slightly elongated quartz. At some domains melt patches were present in which coarse anhedral orthopyroxene occur (up to $1 \mathrm{~cm}$ in diameter) with quartz and feldspars. The sample E/01/13 is a garnet-bearing charnockite, collected from the main dam site of the Moragahakanda Reservoir. The rock contains garnet, orthopyroxene and two feldspars as the major mineral phases while the clinopyroxene and biotite occur as the minor minerals. The rock contains anhedral to subhedral porphyroblastic garnets $(0.5-1.5 \mathrm{~cm}$ in diameter), medium to coarse-grained orthopyroxene $(0.2-1 \mathrm{~cm})$ and recrystallised feldspars and quartz as major mineral phases while clinopyroxene and biotite are found as the minor minerals. The charnockite collected from Godakawela (E/01/18) contains anhedral medium to coarse grained porphyroblastic orthopyroxene and garnet, with recrystallised feldspars and quartz in the matrix.

\section{WHOLE ROCK GEOCHEMISTRY}

Analytical results of major elements, some trace elements and PGE are given in Tables 1 and 2. 


\section{MAJOR ELEMENT CHEMISTRY}

The mafic samples of the $\mathrm{HC}$ are characterized with a narrow $\mathrm{SiO}_{2}$ range $(\sim 42-47$ wt $\%)$, compared to the garnetiferrous charnockites of which $\mathrm{SiO}_{2}$ varies in the range of $\sim 45-70$ wt $\%$ showing mafic to felsic compositions. The $\mathrm{SiO}_{2}$ composition of ultramafic-mafic samples of VC is variable from $\sim 40-50 \mathrm{wt} \%$ with a relatively higher $\mathrm{MgO}$ content from $\sim 18-36 \mathrm{wt} \%$. Charnockitic sample from the VC is $\sim 61 \mathrm{wt} \%$, while that of the $\mathrm{KK}$ has a $\mathrm{SiO}_{2} \sim 68 \mathrm{wt} \%$. Mafic samples of the KK range from $\sim 44$ to $47 \mathrm{wt} \%$. On major element compositional Harker diagrams, samples from each litho-unit show variable geochemical trends (Fig. 2). The compositions of $\mathrm{CaO}$ and $\mathrm{MgO}$ show a negative correlation for samples from all the lithological units (Fig. 2a, b). $\mathrm{TiO}_{2}$ Vs. $\mathrm{SiO}_{2}$ of garnetiferrous charnockitic samples from the $\mathrm{HC}$ and all the samples of the $\mathrm{VC}$ depict a positive correlation whereas those from the $\mathrm{KK}$ and the mafic samples from the $\mathrm{HC}$ show a steep negative slope (Fig. 2d). $\mathrm{Al}_{2} \mathrm{O}_{3}$ Vs. $\mathrm{SiO}_{2}$ shows more-or-less flat variation for the mafic samples except for those from the $\mathrm{HC}$, which has a nearvertical trend at its narrow $\mathrm{SiO}_{2}$ range (Fig. 2e).

According to the above geochemical trends shown in the Fig. 2, some of the major element variation patterns (e.g. $\mathrm{TiO}_{2}, \mathrm{Al}_{2} \mathrm{O}_{3}$ ) distinctly differ from typical magmatic differentiation trends (e.g. Rollinson, 1993), and might be showing a modified behavior, probably due to melt-fluid interactions occurred during the evolution of protolith magma suites. However, the slope of the possible correlation trends of each suite is different, which sufficiently describe that the sample protoliths belong to distinctly different genetical environments. In $\mathrm{FeO} / \mathrm{MgO}$ Vs. $\mathrm{SiO}_{2}$ diagram (after Miyashiro, 1974), most of the mafic samples of the HC and samples of the KK fall geochemically in the tholiietic field (Fig. 2c). In contrast, the garnetiferrous charnockitic samples of the $\mathrm{HC}$ and majority of the $\mathrm{VC}$ samples plot in the calcalkaline field. This feature is consistent with the chemical variation of Sri Lankan rocks observed in previous studies (e.g. Pohl and Emmerman, 1991).

\section{RARE EARTH ELEMENT (REE) CHEMISTRY}

The variations of REE compositions expressed by $\mathrm{La} / \mathrm{Sm} \mathrm{Vs.} \mathrm{Yb} \mathrm{(Fig.} \mathrm{2d),} \mathrm{display} \mathrm{patterns} \mathrm{in}$ which all the samples from the $\mathrm{VC}$ and mafic samples from the HC display more or less flat or slightly positive LREE variation (represented by $\mathrm{La} / \mathrm{Sm}$ ) with increasing HREE (represented by $\mathrm{Yb}$ ). However, the garnetiferrous charnockitic samples from the $\mathrm{HC}$ and all the samples from the KK have steep negative correlations (Fig. 2d). This feature probably indicates that a heavy fractionation of LREE (with respect to HREE) has occurred in protolith magmas responsible for formation of the latter set of samples.

Table 1. Major element composition of the analysed samples

\begin{tabular}{|c|c|c|c|c|c|c|c|c|c|c|c|c|c|c|c|}
\hline $\begin{array}{l}\text { Oxiide } \\
\text { MeasurementUnit }\end{array}$ & Location & $\begin{array}{l}\mathrm{SiO}_{2} \\
\mathrm{wt} \%\end{array}$ & $\begin{array}{l}\mathrm{Al}_{2} \mathrm{O}_{3} \\
\mathrm{wt} \%\end{array}$ & $\begin{array}{l}\mathrm{Fe}_{2} \mathrm{O}_{3}{ }^{*} \\
\text { wt } \%\end{array}$ & $\begin{array}{l}\mathrm{MnO} \\
\mathrm{wt} \%\end{array}$ & $\begin{array}{l}\mathrm{MgO} \\
\mathrm{wt} \%\end{array}$ & $\begin{array}{l}\mathrm{CaO} \\
\mathrm{wt} \%\end{array}$ & $\begin{array}{l}\mathrm{Na}_{2} \mathrm{O} \\
\text { wt } \%\end{array}$ & $\begin{array}{l}\mathrm{K}_{2} \mathrm{O} \\
\mathrm{wt} \%\end{array}$ & $\begin{array}{l}\mathrm{TiO}_{2} \\
\mathrm{wt} \%\end{array}$ & $\begin{array}{l}\mathrm{P}_{2} \mathrm{O}_{5} \\
\mathrm{wt} \%\end{array}$ & $\begin{array}{l}\mathrm{Cr}_{2} \mathrm{O}_{3} \\
\text { wt \% }\end{array}$ & $\begin{array}{l}\mathrm{SO}_{3} \\
\mathrm{wt} \%\end{array}$ & $\begin{array}{c}\text { LOI } \\
\%\end{array}$ & $\begin{array}{c}\text { Total } \\
\%\end{array}$ \\
\hline \multicolumn{16}{|l|}{ Rock Unit/Sample No. } \\
\hline \multicolumn{16}{|l|}{ Vijayan Complex } \\
\hline KIR-6 & Kirinda & 50.05 & 16.81 & 11.02 & 0.14 & 4.76 & 7.44 & 4.46 & 2.17 & 1.77 & 0.57 & 0.01 & 0.03 & 0.67 & 100.21 \\
\hline MAHI/L1 & Mahiyangana & 49.82 & 14.53 & 12.07 & 0.3 & 7.25 & 11.05 & 2.97 & 0.97 & 0.48 & 0.151 & 0.02 & 0.12 & 0.3 & 100.11 \\
\hline MON-1 & Moneragala & 68.55 & 14.25 & 5.32 & 0.08 & 0.56 & 1.87 & 3.37 & 5.03 & 0.57 & 0.202 & $\mathrm{x}$ & 0.07 & 0 & 100.03 \\
\hline $\mathrm{VC} / 2 / 2$ & Ussangoda & 58.25 & 0.28 & 13.38 & 0.09 & 17.86 & 0.08 & $\mathrm{x}$ & 0.01 & 0.01 & 0.006 & 0.74 & & 7.36 & 99.69 \\
\hline $\mathrm{VC} / 3 / 2$ & Indikolapelessa & 39.85 & 0.25 & 7.31 & 0.09 & 35.68 & 0.41 & $\mathrm{x}$ & $\mathrm{x}$ & 0.02 & 0.005 & 0.37 & 0.03 & 15.24 & 99.57 \\
\hline \multicolumn{16}{|l|}{ Highland Complex } \\
\hline $\mathrm{B} / 01 / 08$ & Lenadora & 45.36 & 12.43 & 19.77 & 0.253 & 5.01 & 9.65 & 2.54 & 1.62 & 3.098 & 0.63 & N.A & N.A & -0.37 & 99.98 \\
\hline $\mathrm{B} / 01 / 09$ & Ambuluwawa & 45.76 & 11.13 & 18.73 & 0.247 & 4.02 & 9.97 & 2.38 & 1.08 & 4.085 & 1.24 & N.A & N.A & 0.51 & 99.15 \\
\hline $\mathrm{B} / 01 / 12$ & Hunnasgiriya & 41.9 & 14.51 & 8.14 & 0.081 & 15.88 & 12.62 & 1.64 & 2.33 & 0.415 & 0.02 & N.A & N.A & 1.82 & 99.34 \\
\hline $\mathrm{B} / 01 / 14$ & Haputale & 46.46 & 14.6 & 15.01 & 0.208 & 7.86 & 11.65 & 2.44 & 0.62 & 1.656 & 0.22 & N.A & N.A & -0.3 & 100.40 \\
\hline $\mathrm{B} / 01 / 16$ & Koslanda & 47.07 & 15.64 & 15.26 & 0.227 & 7.57 & 12.31 & 2 & 0.13 & 1.165 & 0.09 & N.A & N.A & -0.58 & 100.90 \\
\hline $\mathrm{E} / 01 / 08$ & Randenigala & 69.89 & 12.74 & 6.65 & 0.1 & 1.75 & 2.35 & 2.49 & 2.96 & 0.87 & 0.191 & $\mathrm{x}$ & 0.13 & -0.1 & 100.05 \\
\hline $\mathrm{E} / 01 / 13$ & Moragahakanda & 45.01 & 14.44 & 11.17 & 0.2 & 11.55 & 12.73 & 0.99 & 1.55 & 0.49 & 0.145 & 0.02 & 0.99 & 1.35 & 99.89 \\
\hline $\mathrm{E} / 01 / 18$ & Godakawela & 56.91 & 15.37 & 8.05 & 0.17 & 5.91 & 4.53 & 4.24 & 2.52 & 0.93 & 0.333 & 0.03 & 0.22 & 0.34 & 99.56 \\
\hline \multicolumn{16}{|l|}{ Kataragama Klippe } \\
\hline KATA/L1-1 & Beralihela & 51.42 & 14.7 & 11.65 & 0.18 & 6.16 & 8.59 & 4.31 & 1.7 & 0.86 & 0.131 & 0.03 & 0.05 & 0.37 & 100.39 \\
\hline KATA/L1-2 & Kataragama & 46.74 & 13.4 & 16.44 & 0.21 & 5.68 & 9.26 & 3.89 & 1.28 & 2.1 & 0.353 & 0.02 & 0.17 & -0.17 & 99.48 \\
\hline KATA/L3 & Kataragama & 61.15 & 12.28 & 10.73 & 0.15 & 5.28 & 3.64 & 1.52 & 2.99 & 1.29 & 0.171 & 0.01 & 0.02 & 0.23 & 99.67 \\
\hline KATA/L $5 / 2$ & Galhena & 47.38 & 13.62 & 14.35 & 0.22 & 7.97 & 9.83 & 3.36 & 0.75 & 1.57 & 0.121 & 0.02 & 0.27 & 0.5 & 99.90 \\
\hline KATA/13 & Andarawewa & 44.14 & 13.59 & 19.03 & 0.32 & 3.72 & 6.47 & 3.84 & 3.49 & 2.69 & 1.859 & $\mathrm{x}$ & 0.27 & 0.6 & 100.16 \\
\hline
\end{tabular}


Table 2. Gold, platinum group element, selected trace and rare earth element composition of the analysed samples

\begin{tabular}{|c|c|c|c|c|c|c|c|c|c|c|c|c|c|c|}
\hline $\begin{array}{l}\text { Element/ratio } \\
\text { Measurement Unit }\end{array}$ & Location & $\begin{array}{c}\mathrm{Au} \\
\mathrm{ppb}\end{array}$ & $\begin{array}{c}\text { Ir } \\
\mathrm{ppb}\end{array}$ & $\begin{array}{l}\mathrm{Pd} \\
\mathrm{ppb}\end{array}$ & $\begin{array}{c}\mathrm{Pt} \\
\mathrm{ppb}\end{array}$ & $\begin{array}{l}\mathrm{Rh} \\
\mathrm{ppb}\end{array}$ & $\begin{array}{l}\mathrm{Ru} \\
\mathrm{ppb}\end{array}$ & $\begin{array}{c}\mathrm{Rb} \\
\mathrm{ppm}\end{array}$ & $\begin{array}{c}\mathrm{La} \\
\mathrm{ppm}\end{array}$ & $\begin{array}{l}\mathrm{Sm} \\
\mathrm{ppm}\end{array}$ & $\begin{array}{r}\mathrm{Yb} \\
\mathrm{ppm}\end{array}$ & $\mathrm{FeO} / \mathrm{MgO}$ & $\mathrm{La} / \mathrm{Sm}$ & PtPd \\
\hline \multirow{2}{*}{\multicolumn{15}{|c|}{$\begin{array}{l}\text { Rock Unit/Sample No. } \\
\text { Vijayan Complex }\end{array}$}} \\
\hline & \multicolumn{14}{|c|}{ Vijayan Complex } \\
\hline KIR-6 & Kirinda & 5 & $\mathrm{X}$ & 1 & 2 & $\mathrm{X}$ & $\mathrm{X}$ & 0.4 & 28.6 & 6.5 & 3.1 & 2.3 & 4.4 & 2.0 \\
\hline MAHI/L1 & Mahiyangana & 7 & $\mathrm{X}$ & 4 & 3 & $\mathrm{X}$ & $\mathrm{x}$ & 0.3 & 11.7 & 3.4 & 1.8 & 1.7 & 3.4 & 0.8 \\
\hline MON-1 & Moneragala & 15 & $\mathrm{X}$ & 1 & 3 & $\mathrm{X}$ & $\mathrm{X}$ & 0.7 & 50.3 & 12.4 & 5.4 & 9.5 & 4.1 & 3.0 \\
\hline $\mathrm{VC} / 2 / 2$ & Ussangoda & 9 & 8 & 1 & 7 & 2 & 13 & 0.1 & 3 & 1.3 & 0.8 & 0.7 & 2.3 & 7.0 \\
\hline $\mathrm{VC} / 3 / 2$ & Indikolapelessa & 3 & 3 & 2 & 4 & 1 & 4 & $\mathrm{X}$ & 0.5 & $\mathrm{X}$ & $\mathrm{X}$ & 0.2 & & 2.0 \\
\hline \multicolumn{15}{|l|}{ Highland Complex } \\
\hline $\mathrm{B} / 01 / 08$ & Lenadora & 6 & $\mathrm{X}$ & 27 & 16 & 1 & 15 & 26 & 34.5 & 10.3 & 7.87 & 3.9 & 3.3 & 0.6 \\
\hline B/01/09 & Ambuluwawa & 8 & 1 & 3 & 2 & $\mathrm{X}$ & $\mathrm{X}$ & 45 & 53 & 23 & 9.34 & 4.7 & 2.3 & 0.7 \\
\hline $\mathrm{B} / 01 / 12$ & Hunnasgiriya & $\mathrm{X}$ & $\mathrm{X}$ & 8 & 3 & $\mathrm{X}$ & $\mathrm{X}$ & 37 & 38.6 & 18.6 & 5.27 & 0.5 & 2.1 & 0.4 \\
\hline $\mathrm{B} / 01 / 14$ & Haputale & 3 & $\mathrm{X}$ & 8 & 4 & $\mathrm{X}$ & 5 & 7 & 12 & 4.93 & 3.89 & 1.9 & 2.4 & 0.5 \\
\hline $\mathrm{B} / 01 / 16$ & Koslanda & 1 & $\mathrm{X}$ & 3 & 2 & $\mathrm{X}$ & $\mathrm{X}$ & $\mathrm{X}$ & 3.74 & 2.55 & 3.02 & 2.0 & 1.5 & 0.7 \\
\hline E/01/08 & Randenigala & $\mathrm{X}$ & $\mathrm{X}$ & 2 & 1 & $\mathrm{X}$ & $\mathrm{X}$ & 0.8 & 53 & 9.4 & 5.7 & 3.8 & 5.6 & 0.5 \\
\hline $\mathrm{E} / 01 / 13$ & Moragahakanda & 3 & $\mathrm{X}$ & 3 & 4 & $\mathrm{X}$ & $\mathrm{X}$ & 0.6 & 18.6 & 5.1 & 5 & 1.0 & 3.6 & 1.3 \\
\hline $\mathrm{E} / 01 / 18$ & Godakawela & 6 & $\mathrm{X}$ & 2 & 2 & $\mathrm{X}$ & 1 & 0.4 & 45 & 5.8 & 2.5 & 1.4 & 7.8 & 1.0 \\
\hline \multicolumn{15}{|l|}{ Kataragama Klippe } \\
\hline KATA/L1-1 & Beralihela & 5 & $\mathrm{X}$ & 14 & 9 & 1 & $\mathrm{X}$ & 0.5 & 32.6 & 5.9 & 3.7 & 1.9 & 5.5 & 0.6 \\
\hline KATA/L1-2 & Kataragama & 14 & $\mathrm{X}$ & 25 & 16 & 1 & $\mathrm{X}$ & 0.5 & 17.1 & 4.5 & 3.5 & 2.9 & 3.8 & 0.6 \\
\hline KATA/L3 & Kataragama & 4 & $\mathrm{X}$ & 2 & 4 & $\mathrm{X}$ & 2 & 0.5 & 28.7 & 5.9 & 3.4 & 2.0 & 4.9 & 2.0 \\
\hline KATA/L5/2 & Galhena & 5 & $\mathrm{X}$ & 3 & 2 & $\mathrm{X}$ & 1 & 0.6 & 11.5 & 6.5 & 4.9 & 1.8 & 1.8 & 0.7 \\
\hline KATA/13 & Andarawewa & 5 & $\mathrm{x}$ & 1 & 3 & $\mathrm{X}$ & $\mathrm{X}$ & 1.3 & 61.1 & 22.6 & 7.8 & 5.1 & 2.7 & 3.0 \\
\hline
\end{tabular}

\section{GOLD AND PLATINUM GROUP ELEMENT GEOCHEMISTRY}

The samples from Kataragama, Vijayan and Highland terrains contain $\mathrm{Au}$ content-ranges of 5-14, 3-15 and 1-8 ppb, respectively. The PGE, especially $\mathrm{Pd}$ and $\mathrm{Pt}$ are contained in ranges of 1-25 and 2-16, 1-4 and 2-7 and 3-27 and 1-16 $\mathrm{ppb}$, in the above litho-units, respectively. The highest $\mathrm{Au}$ and $\mathrm{Pt}$ contents are reported from the VC samples, whereas the highest Pd contents are reported from a sample from the HC (Table 2). The samples of VC, KK and mafic samples from the HC show a negative (near vertical) correlation in the $\mathrm{Au}$ Vs. $\mathrm{MgO}$ diagram (Fig. 3 a). In contrast, the $\mathrm{Au}$ and $\mathrm{PGE}$ of garnetiferrous charnockites of $\mathrm{HC}$ show an opposite correlation with increasing $\mathrm{MgO}$ contents (Fig. 3a). In addition, interestingly, the correlation of $\mathrm{Pt} / \mathrm{Pd}$ and $\mathrm{Au} / \mathrm{Pt}$ vs. $\mathrm{MgO}$ is negative for all the samples (with variable slopes), except for garnetiferrous charnockites from the HC (Fig. $3 \mathrm{~b}, \mathrm{c})$. Further, the PGE-MgO relationships shown by the mafic gneiss samples of the $\mathrm{HC}$ are consistent with a previous study of Malaviarachchi and Dharmapriya, 2014, who reported PGE and $\mathrm{Au}$ compositions of high magnesian granulites from the $\mathrm{HC}$.

\section{DISCUSSION}

\section{RARE EARTH AND CHALCOPHILE ELEMENT BEHAVIOR OF PROTOLITH MAGMAS OF THE SRI LANKAN META-IGNEOUS ROCKS}

The petrography and whole rock compositions reveal that the studied samples vary range from ultramafic-mafic to granitic (including both mafic and felsic charnockites) (Table 1; Fig. 1). Our major element and combined Au and PGE data clearly show different trends in geochemical discrimination plots, indicating that the samples from each lithological unit have different genetical environments unrelated to each other (Fig. 2). The REE data evidence that the magmatic protoliths of garnetiferrous charnockites in the $\mathrm{HC}$ have negative correlation in LREE Vs. HREE plots (Fig. 2f) and are consistent with a typical magmatic differentiation trend produced by during partial melting/fractional crystalization. In contrary, geochemical trends displayed by all other samples seems to be disturbed or deviate away from typical differentiation patterns (usually, when partial melts are produced HREE prefer to stay in the residue which is reflected by a depletion of particular element/s in the melt giving a negative correlation). 

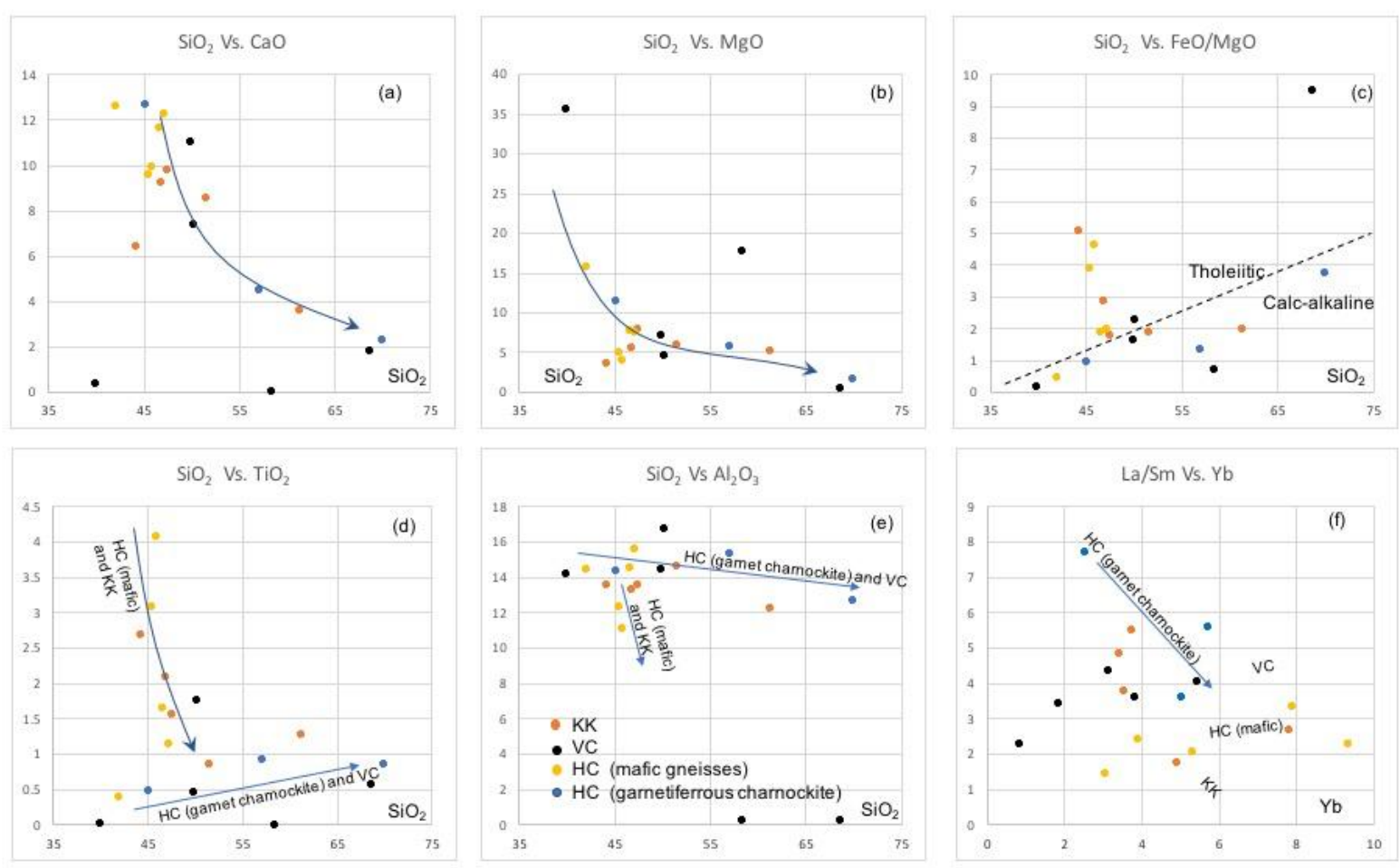

Fig. 2. Major element variation (Harker diagrams, a-e) and LREE Vs. HREE (represented by La/Sm and $Y$ b, respectively in $f$ ) of the studied samples. In $c$, tholeiitic and calc-alkaline classification is after Miyashiro, 1974. See text for details on geochemical trends shown by arrows.

This disturbed behavior could be explained due to transport and remobilization of LREE of magmatic protoliths in response to a later interaction with other fluids or melts (e.g. Boudreau \& Meurer, 1999). Alternatively, it is also possible that the LREE become fractionated into trapped interstitial liquid in some rocks which could make a contrasting influence on partition coefficients of $\mathrm{La}$ and $\mathrm{Yb}$ with melt (e.g. Boudreau \& Meurer, 1999 and references therein). This is particularly important even for metamorphic rocks (such as those studied here) which are highly retrogressed, implying hydrous melts get impregnated during decompression. However, our petrographic observations rule out occurrence of interstitial liquids in the matrix (only retrogression is evidenced by occurrence of biotite and amphibole), and therefore we interpret that the disturbances depicted in REE in samples of the $\mathrm{VC}$, $\mathrm{KK}$ and $\mathrm{HC}$ (mafic) could be attributed to interactions with a percolating melt/fluid which formed hydrous minerals, probably during assent from lower crustal levels. The Au and PGE element (e.g. Pt, Pd) variation with respect to increasing $\mathrm{MgO}$ contents are shown in the Fig. 3a, b, c. Accordingly, it is inferred that variation patterns of precious metals in the studied samples are not simply related to lithology or their felsic or mafic character. For example, the garnetiferrous charnockitic samples from the HC show a positive correlation while the mafic samples show a clear negative correlation in the above figure. In contrast, the samples of $\mathrm{KK}$ and VC are characterized with a negative, but variable $\mathrm{Pt} / \mathrm{Pd}$ and $\mathrm{Au} / \mathrm{Pt}$ distribution patterns with different slopes incomparable to each other. 

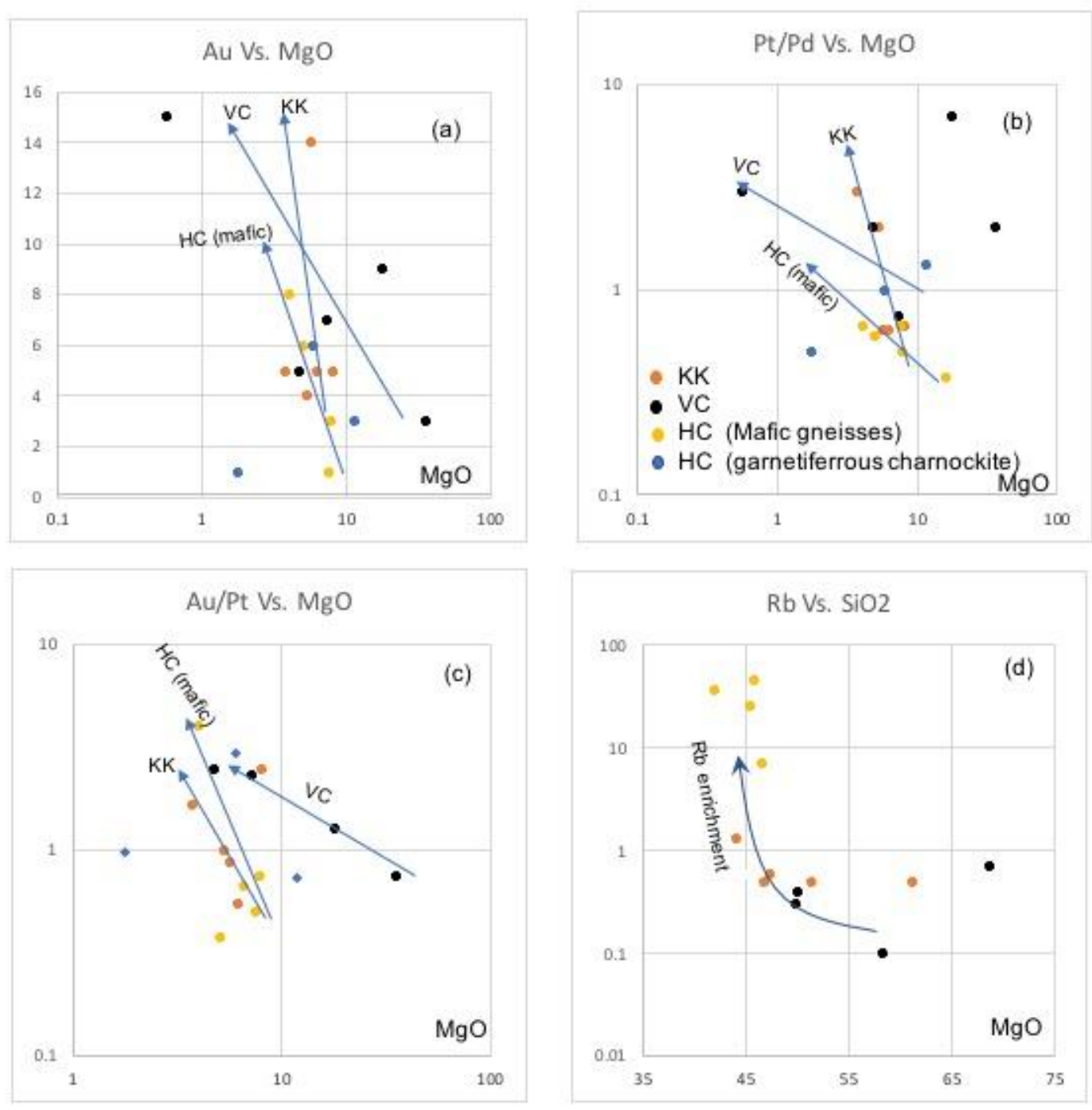

Fig. 3. Geochemical variation shown by $A u$ and $P G E(a-c)$ and Rb plotted against $M g O$ contents $(d)$ of the studied samples. See text for details on geochemical trends shown by arrows.

Such patterns in chalcophile elements are usually attributed to interaction with suphidebearing melts (calchophile elements prefer sulphide-melts particularly under reduced conditions; e.g. Naldrett et al., 1987, 1990; Park et al. 2013, 2015). These melts are likely to interact with silicate melts/magma causing deviations of chalcophile elements from any fractionation/differentiation trend, as seen from the samples of the KK, VC and HC (mafic) (Fig. 3 a,b,c). Possible candidate for such interactive melts is reduced alkaline magmas containing higher amounts of PGE contents than normal basaltic magma (e.g. Maier and Barnes, 2004) which are responsible for transport and remobilization of PGE (Boudreau \& McCullum, 1992; Boudreau \& Meurer, 1999). Tectonically, reduced magmas are possible to form in extension related settings, and hence the alkaline magmas interacted with the above samples in the $\mathrm{KK}, \mathrm{VC}$ and $\mathrm{HC}$ could have intruded during extension suffered soon after collision of the Vijayan magmatic arc with the HC (E.g. Kehelpannala, 2003; Santosh et al. 2014; He et al. 2016). Further, this hypothesis is in-line with alkaline trace element (e.g. $\mathrm{Rb}$ ) variation in our samples as shown in the Fig. $3 \mathrm{c}$ which depicts the majority of samples of the KK and VC have a geochemical trend in the direction of $\mathrm{Rb}$ enrichments. This enrichment pattern trends 
Table 3. Estimated amount of gold, platinum, palladium and ruthenium in Sri Lankan rocks

\begin{tabular}{|c|c|c|c|c|c|c|c|}
\hline \multirow{3}{*}{$\begin{array}{l}\text { Element } \\
\text { Measurement Unit }\end{array}$} & \multirow[b]{3}{*}{ Location } & \multicolumn{3}{|c|}{ M easured amount } & \multicolumn{3}{|c|}{ Estmated amount } \\
\hline & & $\mathrm{Au}$ & $\mathrm{Pd}$ & $\mathrm{Pt}$ & $\mathrm{Au}$ & $\mathrm{Pd}$ & $\mathrm{Pt}$ \\
\hline & & $\mathrm{ppb}$ & $\mathrm{ppb}$ & $\mathrm{ppb}$ & $\mathrm{g} / \mathrm{ton}$ & $\mathrm{g} / \mathrm{ton}$ & $\mathrm{g} / \mathrm{ton}$ \\
\hline \multirow{2}{*}{\multicolumn{8}{|c|}{$\begin{array}{l}\text { Rock Unit/Sample No. } \\
\text { Vijayan Complex }\end{array}$}} \\
\hline & & & & & & & \\
\hline KIR-6 & Kirinda & 5 & 1 & 2 & 0.005 & 0.001 & 0.002 \\
\hline MAHI/L1 & Mahiyangana & 7 & 4 & 3 & 0.007 & 0.004 & 0.003 \\
\hline MON-1 & Moneragala & 15 & 1 & 3 & 0.015 & 0.001 & 0.003 \\
\hline $\mathrm{VC} / 2 / 2$ & Ussangoda & 9 & 1 & 7 & 0.009 & 0.001 & 0.007 \\
\hline $\mathrm{VC} / 3 / 2$ & Indikolapelessa & 3 & 2 & 4 & 0.003 & 0.002 & 0.004 \\
\hline \multicolumn{5}{|c|}{$\begin{array}{l}\text { Average estimated content (mg/ton) } \\
\end{array}$} & 8 & 2 & 4 \\
\hline \multicolumn{8}{|c|}{ Highland Complex } \\
\hline $\mathrm{B} / 01 / 08$ & Lenadora & 6 & 27 & 16 & 0.006 & 0.027 & 0.016 \\
\hline $\mathrm{B} / 01 / 09$ & Ambuluwawa & 8 & 3 & 2 & 0.008 & 0.003 & 0.002 \\
\hline $\mathrm{B} / 01 / 12$ & Hunnasgiriya & & 8 & 3 & & 0.008 & 0.003 \\
\hline $\mathrm{B} / 01 / 14$ & Haputale & 3 & 8 & 4 & 0.003 & 0.008 & 0.004 \\
\hline $\mathrm{B} / 01 / 16$ & Koslanda & 1 & 3 & 2 & 0.001 & 0.003 & 0.002 \\
\hline $\mathrm{E} / 01 / 08$ & Randenigala & & 2 & 1 & & 0.002 & 0.001 \\
\hline $\mathrm{E} / 01 / 13$ & Moragahakanda & 3 & 3 & 4 & 0.003 & 0.003 & 0.004 \\
\hline $\mathrm{E} / 01 / 18$ & Godakawela & 6 & 2 & 2 & 0.006 & 0.002 & 0.002 \\
\hline \multicolumn{5}{|c|}{ Average estimated content (mg/ton) } & 4 & 7 & 4 \\
\hline \multicolumn{8}{|c|}{ Kataragama Klippe } \\
\hline KATA/L1-1 & Beralihela & 5 & 14 & 9 & 0.005 & 0.014 & 0.009 \\
\hline KATA/L1-2 & Kataragama & 14 & 25 & 16 & 0.014 & 0.025 & 0.016 \\
\hline KATA/L3 & Kataragama & 4 & 2 & 4 & 0.004 & 0.002 & 0.004 \\
\hline KATA/L5/2 & Galhena & 5 & 3 & 2 & 0.005 & 0.003 & 0.002 \\
\hline KATA/13 & Andarawewa & 5 & 1 & 3 & 0.005 & 0.001 & 0.003 \\
\hline \multicolumn{5}{|c|}{ Average estimated content (mg/ton) } & 7 & 9 & 7 \\
\hline \multicolumn{5}{|c|}{ Amounts mined in Ore-grade rocks worldwide* } & $>1 \mathrm{~g} / \mathrm{ton}$ & $>2-3 \mathrm{~g} /$ ton & $>0.5 \mathrm{~g} / \mathrm{ton}$ \\
\hline
\end{tabular}

towards the $\mathrm{Rb}$ composition of the $\mathrm{HC}$ (mafic) samples, indicating that the mafic alkaline magmas intruded into the HC may have had an interaction with the $\mathrm{KK}$ and $\mathrm{VC}$ terrain rocks, probably during the $\mathrm{HC}-\mathrm{VC}$ post collisional rifting.

The higher elemental mobility/incompatibility of $\mathrm{Pd}$ and Au compared to that of Pt help to utilize the variability of $\mathrm{Pt} / \mathrm{Pd}$ and $\mathrm{Au} / \mathrm{Pt}$ against $\mathrm{MgO}$ in rocks (see Francis, 1990). This geochemical ratio helps to identify whether a precious metal bearing fraction of magma is formed (in other words, an immiscible chalcophile melt). There is a clear distinction of $\mathrm{Pt} / \mathrm{Pd}$ vs. $\mathrm{MgO}$ (Fig. 3b), in which all the samples except for garnetiferrous charnockites from the HC show a negative correlation. This negative correlation shown by the $\mathrm{Pt} / \mathrm{Pd}$ against $\mathrm{MgO}$ is a solid evidence for segregation of sulphide melts from respective magmas (Park et al., 2013, 2015; Hao et al., 2017; Lowczak et al., 2017). The geochemical trend shown by $\mathrm{Au} / \mathrm{Pt}$ of the studied samples is also more-or-less similar with that of the $\mathrm{Pt} / \mathrm{Pd}$ (Fig. 3c).

Thus, the above variation of chalcophile elemental ratios (increasing elemental contents and their ratios with decreasing $\mathrm{MgO}$ contents) is a robust evidence to infer progressive segregation of an immiscible sulfide melt during magmatic evolution, which ultimately cause chalcophile element enrichments or mineralization associated with the rock suite formed by the particular magma (e.g. Campbell and Barnes, 1984; Setiabudi et al. 2007).

Hence, our present geochemical data from the three litho-units of Sri Lanka convincingly indicate that the possibility for occurrence of 
precious (calcophile) metals within the metaigneous rock units of the $\mathrm{VC}$ and $\mathrm{KK}$ is high. However, for the $\mathrm{HC}$, the possibility is there for mafic rock associations and, it is ruled out for the charnockitic rock associations. Therefore, in the future, resource estimation of precious metals is also important for prospective explorations considering the appropriate rock types.

\section{RESOURCE ESTIMATION OF PRECIOUS METALS IN SRI LANKAN META-IGNEOUS ROCKS}

In general, 'mineability' of metals in rocks could be estimated based on geochemical data, provided that the rocks are homogeneous in whole-rock scale. As far as the scale of the sampling carried out and petrographic features of the specimens in this study are concerned, all the studied meta igneous rocks could be considered to be of homogenous in whole-rock chemistry. Hence, the estimated amounts of precious metals (Au and PGE) based on bulk chemistry which are expected to be in the prospective rock units of Sri Lanka are presented in the Table 3 in comparison with oregrade precious metal contents from elsewhere in the world. Accordingly, the $\mathrm{VC}, \mathrm{KK}$ and $\mathrm{HC}$ contain ca. 8, 7 and 4, 2, 9 and 7, 4, 7 and 4 of $\mathrm{Au}, \mathrm{Pd}$ and $\mathrm{Pt}$ (mg/ton) in average, respectively. Further, it should be noted that these precious metal estimates are below the gold/PGE oregrade which is usually of levels above several ppm (0.5-3 g/ton) per each element (e.g. Emawati et al. 2017; Kasrai et al. 1988). However, the Table 3 shows that precious metal contents present in our rocks are still high enough to be extracted in-situ at small scale as 'hard rock mining', similar to the practices employed for hard-rock gem mining in many regions of India as a small-scale industry.

\section{CONCLUSIONS}

The geochemical variation patterns of precious metals in the studied samples are not simply related to their felsic or mafic character. Discovered geochemical characteristics imply that the variation of Au and PGE of the studied samples from the $\mathrm{VC}, \mathrm{KK}$ and $\mathrm{HC}$ could be explained by involvement of a reducedmelt/magma since chalcophile metals could easily be partitioned into such melts. Subsequent interaction by secondary fluids/melts during the evolution of their protoliths is also evident from all the samples except for garnetiferrous charnockites of the HC. Since the studied samples are metamorphosed rocks, there is a high possibility for secondary fluids available during retrograde metamorphism to interact with and is amply supported by alkaline elemental enrichments and petrographic observations of hydrous mineral growth in the matrix.

Therefore, we conclude that there is a tendency of $\mathrm{Au}, \mathrm{Pt}$ and $\mathrm{Pd}$, to be ubiquitously concentrated within the meta-igneous rocks of the $\mathrm{VC}, \mathrm{KK}$ and $\mathrm{HC}$ terrains. However, the present data rules out the probability for precious metals to be accumulated associated with garnetiferrous charnockitic rocks of the $\mathrm{HC}$, as they do not account for any geochemical evidence sensitive to chalcophile behavior of the above elements. This could be explained as garnetiferrous charnockites in the HC may have not been affected by rift related magmatism (or reduced magma, which prefer chalcophile elements to be partitioned into).

Thus, it is recommended that detailed investigations are necessary incorporating $\mathrm{Au}$ and PGE geochemistry from other sections of the $\mathrm{HC}$ and $\mathrm{VC}$ in the future, so that a database for precious metals in the Sri Lankan basement could be constructed in order to evaluate their spatial variability in concentration and economic feasibility for extraction. Our estimates show that highest average $\mathrm{Au}, \mathrm{Pt}$ and $\mathrm{Pd}$ contents are found in $\mathrm{VC}$ ( $8 \mathrm{mg} / \mathrm{ton}), \mathrm{KK}$ ( $7 \mathrm{mg} / \mathrm{ton})$ and $\mathrm{HC}$ (7 $\mathrm{mg} / \mathrm{ton}$ ), respectively. Although these precious metals (gold/platinum) contents in the studied rock units are low in concentration to recommend as ore-grade, 'hard rock mining' could be utilized to extract them as a small-scale exploration technique, similar to the practice of hard-rock gem mining in most of villages in India. . Especially, these findings will help people to re-think on usage of quarry-waste 
materials such as fine rock aggregates/rock powder after rock blasts in numerous rockquarries to extract precious metals as a smallscale industry in Sri Lanka.

\section{ACKNOWLEDGEMENTS}

The first author wishes to gratefully acknowledge the financial support from the National Research Council, Sri Lanka (Grant No:NRC-15-089) to initiate the gold and PGE investigations in Sri Lankan rocks. Assistance for initial sample preparations from Mr. S. Opatha and Miss. Thilini Harischandra at NIFS, Kandy is gratefully acknowledged.

\section{REFERENCES}

Audétat A., Simon A.C., (2012) Magmatic Controls on Porphyry Copper Genesis. In: Hedenquist JW, Harris M, Camus F eds) Geology and Genesis of Major Copper Deposits and Districts of the World: A Tribute to Richard H Sillitoe, vol 16. Society of Economic Geologists, pp 553-572.

Barnes S.J., Maier W. D., Keays R. R., Lesher C. M., Lightfoot P. C., Farrow C. E. G., editors. (1999) The fractionation of $\mathrm{Ni}, \mathrm{Cu}$ and the noble metals in silicate and sulphide liquids. Dynamic Processes in Magmatic Ore Deposits and their Application to Mineral Exploration. Geological Association of Canada, Short Course Notes 1999;13:69-106.

Bezmen N.I., Asif M., Bru“gmann G.E., Romanenko I.M., Naldrett A.J., (1994) Distribution of Pd, Rh, $\mathrm{Ru}, \mathrm{Ir}$, Os, and $\mathrm{Au}$ between sulfide and silicate metals. Geochim Cosmochim Acta 58:12511260 .

Boudreau, A.E., McCallum, I.S., (1992) Infiltration metasomatism in layered intrusions - An example from the Stillwater Complex, Montana. Journal of Volcanology and Geothermal Research v. 52, 171-183.

Boudreau, A.E., Meurer, W.P., (1999) Chromatographic separation of the platinumgroup elements, gold, base metals and sulfur during degassing of a compacting and solidifying crystal pile. Contributions to Mineralogy and Petrology v. 134, 174-185.

Boyle, R.W., (1979) The geochemistry of gold and its deposits. Geological Survey of Canada, 280, $584 \mathrm{p}$.
Burnham C.W., (1967) Hydrothermal fluids at the magmatic stage. In: Barnes HL (ed) Geochemistry of Hydrothermal Ore Deposits, vol. Holt Rinehar and Winston, pp 34-76.

Campbell, I.H., S.J. Barnes., (1984) A model for the geochemistry of platinum group elements in magmatic sulphide deposits. Canadian Mineralogist, 22, 151-160.

Cooray, P.G., (1994) The Precambrian of Sri Lanka: a historic review. Precambrian Res. 66, 3-18.

Cooray, P.G., (1962) Charnockites and their associated gneisses in the Precambrian of Ceylon. J. Geol. Soc. London 118, 239- 273.

Cooray, P.G., (1984) An introduction to the geology of Sri Lanka. National Museum Sri Lanka Publication, 340.

Crocket J.H., Fleet M.E., Stone W.E., (1997) Implications of composition for experimental partitioning of platinum-group elements and gold between sulfide liquid and basalt melt: the significance of nickel content. Geochim Cosmochim Acta 61:4139-4149.

Dharmapriya, P.L., Malaviarachchi, S.P.K., Galli, A., $\mathrm{Su}$, B., Subasinghe, N.D., Dissanayake, C.B., Nimalsiri, T.B., Zhu, B., (2014). P-T evolution of a spinel + quartz bearing khondalite from the Highland Complex, Sri Lanka: Implications for non-UHT metamorphism, Journal of Asian Earth Science.DOI: http://dx.doi.org/10.1016/j.jseaes.2014.05.003.

Dissanayake C.B., Chandrajith R., (1999) Sri LankaMadagascar Gondwana linkage: Evidence for a Pan-African mineral belt. Journal of Geology 107: 223-235.

Dissanayake, C.B., Nawaratne, S.W., (1981) The occurrence of gold in the gem beds of Sri Lanka. Economic Geology 76 (3): 733-738.

Dissanayake, C.B., Kritsotakis, K., (1984) The geochemistry of $\mathrm{Au}$ and $\mathrm{Pt}$ in peat and algal mats - A case study from Sri Lanka. Chemical Geology, 42, 61-76.

Ernawati, R., Arifudin I., Himawan T.B.M.P., (2017) Gold grade of epithermal gold ore at Lamuntet, Brang Rea, West Sumbawa District, West Nusa Tenggara Province, Indonesia. AIP Conference Proceedings 1855, 050002 (2017); doi: $10.1063 / 1.4985516$

Fonseca R.O.C., Campbell I.H., O’Neill H.S.C., Allen C.M., (2009). Solubility of Pt in sulphide mattes: implications for the genesis of PGE-rich 
horizons in layered intrusions. Geochim Cosmochim Acta 73:5764-5777.

Francis R.D., (1990) Sulfide globules in midocean ridge basalts (MORB), and the effect of oxygen abundance in Fe-S-O liquids on the ability of those liquids to partition metals from Morb and Komatiite magmas. Chem. Geol 85:199-213.

Goldschmidt, V., (1937) The principles of distribution of chemical elements in minerals and rocks. The seventh Hugo Müller Lecture, delivered before the Chemical Society", Journal of the Chemical Society: 655-673.

Hao H., Campbell I.H., Park J.W., Cooke D.R., (2017) Platinum-group element geochemistry used to determine $\mathrm{Cu}$ and $\mathrm{Au}$ fertility in the Northparkes igneous suites, New South Wales, Australia. Geochim Cosmochim Acta 216:372392.

Hapuarachchi, D.J.A.C., (1968) Cordierite and wollastonite-bearing rocks of south-west of Ceylon. Geol. Mag. 105, 317-324.

Hatherton, T., Pattiarachchi, D.B., Ranasinghe, V.V.C., (1975) Gravity map of Sri Lanka, 1:1,000,000. Geol. Surv. Dept., Sri Lanka, Prof. Paper 3, 39.

He, Xiao-Fang, Santosh, M., Tsunogae., Dharmapriya, P.L., (2016) Neoproterozoic arc accretion along the 'eastern suture' in Sri Lanka during Gondwana assembly. Precambrian Research, 279.

Jenner F.E., O'Neill H.S.C., Arculus R.J., Mavrogenes J.A., (2010) The magnetite crisis in the evolution of Arc-related magmas and the initial concentration of $\mathrm{Au}, \mathrm{Ag}$ and $\mathrm{Cu}$. J Petrol 51(12):2445-2464.

Kasrai, M., Fozoonmayeh, L., Payrovan, H., (1988) Quantitative determination of gold in ore using energy-dispersive XRF spectrometry. Doi:https://doi.org/10.1002/xrs.1300170605.

Keays, R.R., (1995) T role of komatiitic and picritic magmatsm and S-saturation in the formation of ore deposits. Lithos, 34, 1-18.

Kehelpannala, K.V.W., (2003) Structural evolution of the middle to lower crust in Sri Lanka-a review. J. Geol. Soc. Sri Lanka 11, 45-86.

Kehelpannala, K.V.W., (2004) Arc accretion around Sri Lanka during the assembly of Gondwana. Gondwana Res. 7, 1323-1328.

Kriegsman, L., (1994) Evidence for a fold nappe in the high-grade basement of central Sri Lanka: terrane assembly in the Pan-African lower crust? Precambrian Res. 66, 59-76.

Kröner, A., Cooray, P. G., Vitanage, P.W., (1991) Lithotectonic subdivision of the Precambrian basement in Sri Lanka:in Kröner,A.,eds., The Crystalline Crust of Sri Lanka, Part-1. Summary of Research of the German-Sri Lankan Consortium. Geological Survey Department, Sri Lanka, Professional Paper 5, p. 5-21.

Kröner, A., Kehelpannala, K.V.W., Hegner, E., (2003) Ca. 700-1000 Ma magmatic events and Grenvillian-age deformation in Sri Lanka: relevance for Rodinia supercontinent formation and dispersal, and Gondwana amalgamation: Journal of Asian Earth Science,v. 22, p. 279-300.

Kröner, A., Kehelpannala, K.V.W., Hegner, A., (2003) Ca. 750-1100 Ma magmatic events and Grenville-age deformation in Sri Lanka: relevance for Rodinia supercontinent formation and dispersal, and Gondwana amalgamation. J. Asian Earth Sci. 22, 279-300.

Kröner, A., Rojas-Agramonte, Y., Kehelpannala, K. V. W., Zack, T., Hegner, E., Geng, H. Y., Wong, J., Barth, M., (2013) Age, Nd-Hf isotopes, and geochemistry of the Vijayan Complex of eastern and southern Sri Lanka: A Grenville-age magmatic arc of unknown derivation, Precambrian Res. 234, 288-321.

Kröner, A., Rojas-Agramonte, Y., Kehelpannala, K.V.W., Zack, T., Hegner, E., Geng, H.Y., Wong, J., Barth, M., (2013) Age, Nd-Hf isotopes, and geochemistry of the Vijayan Complex of eastern and southern Sri Lanka: a Grenville-age magmatic arc of unknown derivation: Precambrian Research, v. 234, p. 288-321.

Kröner, A., Williams, I.S., Compston, W., Baur, N., Vitanage, P.W., Perera, L.R.K., (1987) Zircon ion microprobe dating of high grade rocks in Sri Lanka:Journal of Geologyv. 95, p. 775-791.

Lorand J. P., (1989) Mineralogy and chemistry of $\mathrm{Cu}-\mathrm{Fe}-\mathrm{Ni}$ sulfides in orogenic-type spinel peridotite bodies from Ariege (northeastern Pyrenees, France). Contrib. Mineral. Petr. 103, 335-345.

Maier W. D. Barnes S.J., (2004) Pt/Pd and Pd/Ir ratios in mantle-derived magmas: a possible role for mantle metasomatism. South African Journal of Geology. 107, 333-340.

Malaviarachchi, Sanjeewa P.K., Dharmapriya, P.L., (2014) Preliminary data on platinum group element and gold in the Highland Complex, Sri Lanka: A search for hidden sulphide saturation. 
Journal of Geological Society of Sri Lanka Vol. 16 (2014), 29-41.

Mathavan, V, W. K. B. N., Prame, W.K.B.N., Cooray, P.G., (1999) Geology of the high grade Proterozoic terrains of Sri Lanka and the assembly of Gondwana: an update on recent developments, Gondwana Res., 2, 237-250.

Mathavan, V., Fernando G.W.A.R., (2001) Reactions and textures in grossular-wollastonite-scapolite calc-silicate granulites from Maligawila, Sri Lanka. Lithos, 59, 217-232.

Mathez, E. A., (1995) Magmatic metasomatism and the formation of the Merensky reef, Bushveld complex, Contrib. Mineral. Petrol.,119, 277-286.

McDonough, W.F., Sun, S.S., (1995) Composition of the Earth. Chemical Geology 120,223-253.

McInnes B.I.A., McBride J.S., Evans N.J., Lambert D.D., Andrew A.S., (1999) Osmium isotope constraints on ore metal recycling in subduction zones. Science 286(5439):512-516.

Milisenda, C.C., Liew, T.C., Hoffman, A.W., Kröner, A., (1988) Isotopic mapping of age provinces in Precambrian high-grade terrains: Sri Lanka: Journal of Geology, v. 96, p. 608-615.

Miyashiro, A. 1974. Volcanic rock series in island arcs and active continental margins. American Journal of Science, 274, 321-355.

Mungall J.E., (2002) Roasting the mantle: Slab melting and the genesis of major Au and Au-rich $\mathrm{Cu}$ deposits. Geology 30(10):915-918.

Mungall J.E., Brenan J.M., (2014) Partitioning of platinum-group elements and Au between sulfide liquid and basalt and the origins of mantle-crust fractionation of the chalcophile elements. Geochim Cosmochim Acta 125:265-289.

Naldrett A.J., Brugmann G.E., Wilson A. H., (1990) Models for the concentration of PGE in layered intrusions. Can Mineral 28: 389-408.

Naldrett, A. J., Cameron, G., Von Gruenewaldt, G. Sharpe, M. R., (1987) The formation of stratiform PGE deposits in layered intrusions. In: Parsons, I. (ed.) Origins of Igneous Layering. Dordrecht: D. Reidel, pp. 313-397.

Nawaratne, S.W., (1996) The potential for discovery of economic gold mineralization in Sri Lanka, Proceedings of the Annual Research Sessions, University of Peradeniya, Sri Lanka, pp 125-130.

Nawaratne, S.W., Wijeratne, G.N., (1995b) The source of placer gold in the Walawe Ganga basin,
Sri Lanka, Ceylon Journal of Science: Physical Sciences, 2(1): 78-85.

Park J.W., Campbell I.H., Arculus R.J. (2013) Platinum-alloy and sulfur saturation in an arcrelated basalt to rhyolite suite: Evidence from the Pual Ridge lavas, the Eastern Manus Basin. Geochim Cosmochim Acta 101:76-95.

Park J.W., Campbell I.H., Eggins S.M., (2012a) Mnrichment of $\mathrm{Rh}, \mathrm{Ru}$, Ir and Os in $\mathrm{Cr}$ spinels from oxidized magmas: evidence from the Ambae volcano, Vanuatu. Geochim Cosmochim Acta $78: 28-50$

Park J.W., Hu Z.C., Gao S., Campbell I.H., Gong H.J., (2012b) Platinum group element abundances in the upper continental crust revisited - New constraints from analyses of Chinese loess. Geochim Cosmochim Acta 93:63-76.

Park J.W., Campbell I.H., Kim J., (2016) Abundances of platinum group elements in native sulfur condensates from the Niuatahi-Motutahi submarine volcano, Tonga rear arc: Implications for PGE mineralization in porphyry deposits. Geochim Cosmochim Acta 174:236-246.

Park J.W., Campbell I.H., Kim J., Moon J.W., (2015) The role of late sulfide saturation in the formation of a $\mathrm{Cu}$ - and Au-rich magma: Insights from the Platinum group element geochemistry of Niuatahi-Motutahi Lavas, Tonga Rear Arc. J Petrol 56(1):59-81.

Peach C.L., Mathez E.A., Keays R.R., Reeves S.J., (1994) Experimentally determined sulfide meltsilicate melt partition-coefficients for iridium and palladium. Chem Geol 117:361-377.

Perera, L.R.K., (1984) Co-existing cordieritealmandine-A key to the metamorphic history of Sri Lanka. Precambrian Res. 25, 349-364.

Philipp H., Eckhardt J.D., Puchelt H., (2001) Platinum-group elements (PGE) in basalts of the seaward-dipping reflector sequence, SE Greenland coast. J Petrol 42:407-432.

Pohl, J.G., Emmermann, R., (1991) Chemical composition of the Sri Lanka Precambrian, in Kröner, A., eds., The Crystalline Crust of Sri Lanka, Part 1. Summary of Research of the German- Sri Lankan Consortium, Geological Survey Department Sri Lanka Professional Paper 5, p. 94-123.

Prame, W.K.B.N., (1991) Petrology of the Kataragama Klippe, Sri Lanka: evidence for high pressure granulite facies metamorphism and subsequent isobaric cooling. Geological Survey 
Department, Sri Lanka, Professional Paper 5, 200224.

Richards J.P., (2003) Tectono-magmatic precursors for porphyry $\mathrm{Cu}-(\mathrm{Mo}-\mathrm{Au})$ deposit formation. Econ Geol Bull Soc 98(8):1515-1533.

Rollinson, H.R., (1993) Using geochemical data: evolution, presentation, interpretation. Longman Scientific and Technical, England.

Santosh, M., Tsunogae, T., Malaviarachchi, S.P.K., Zhang, Z., Ding, H., Tang, L., Dharmapriya, P.L., (2014) Neoproterozoic crustal evolution in Sri Lanka: in- sights from petrologic, geochemical and zircon $\mathrm{U}-\mathrm{Pb}$ and $\mathrm{Lu}-\mathrm{Hf}$ isotopic data and implications for Gondwana assembly: Precambrian Research, v.255, p. 1-29.

Setiabudi, B.T., Campbell, I.H., Martin, C.E., Allen, C., (2007) Platinum group element geochemistry of andesite intrusions of the Kelian region, East Kalimantan, Indonesia: Implications of gold depletion in the intrusions associated with th Kelian gold deposit. Economic Geology, 102, 95108.

Shiraishi, K., Ellis, D.J. ,Hiroi, Y., Fanning, C.M., Motoyoshi, Y., Nakai, Y., (1994) Cambrian orogenic belt in east Antarctica and Sri Lanka: implications for Gondwana assembly. J. Geol. 102, 47-65.

Sillitoe, R.H., (2010) Porphyry Copper Systems. Economic Geology, 105 (1): 3-41. DOI: https://doi.org/10.2113/gsecongeo.105.1.3.

Thirlwall M. F., Smith A., Graham M., Richard J. Arculus., (1994) High field strength element anomalies in Arc lavas: source or process? Journal of Petrology 35(3). DOI: 10.1093/petrology/35.3.819.

Vitanage, P.W., (1985) Tectonics and mineralization in Sri Lanka. Bull. Geol. Soc. Finland 57, 157168.

Vogel D.C., Keays R.R., (1997) The petrogenesis and platinum-group element geochemistry of the Newer Volcanic Province, Victoria, Australia. Chemical Geol ogy,136:181-204.

Voll, G., Kleinschrodt, R., (1991) Sri Lanka: Structural, magmatic and metamorphic development of a Gondwana fragment. Geological Survey Department, Sri Lanka, Professional Paper 5, 22-52.

Wilkinson J.J., (2013) Triggers for the formation of porphyry ore deposits in magmatic arcs. Nat Geosci 6(11):917-925.
Willbold, M., Hegner, E., Kleinschrodt, R., Stosch, H.G., Kehelpannala, K.V.W., Dulski, P., (2004) Geochemical evidence for a Neoproterozoic magmatic continental margin in Sri Lankarelevence for the Rodinia-Gondwana supercontinental cycle. Precambrian Res., 130, 185-198. 